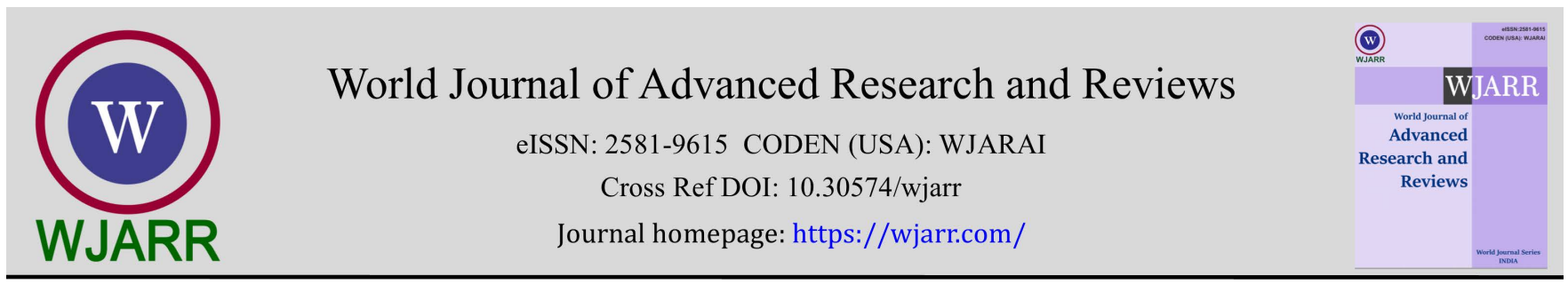

(REVIEW ARTICLE)

\title{
An analysis on the different insurance policy in India and its role in economy growth and providing people with better life opportunities
}

\author{
Dr Sumanta Bhattacharya ${ }^{1,}{ }^{*}$ and Bhavneet Kaur Sachdev ${ }^{2}$ \\ ${ }^{1}$ MAKAUT, Public-Foreign-Defence Policy, MPI (oxford University) ORCID ID: 0000-0003-2563-2787. \\ 2 Political Science hons (Calcutta University), ORCID ID: 0000-0001-9156-0086.
}

World Journal of Advanced Research and Reviews, 2021, 12(03), 119-123

Publication history: Received on 17 October 2021; revised on 03 December 2021; accepted on 05 December 2021

Article DOI: https://doi.org/10.30574/wjarr.2021.12.3.0993

\begin{abstract}
A update financial system is a very necessary for the economy growth, insurance industry provides freedom security for the future to all its citizen. In India the government and the insurance industry works together to provide maximum benefit to its people in the form of life and non-life insurance which includes health, travel and vehicle insurance, it is a very old industry, exiting since ancient times in different form, with privatization, we see a rapid rise in insurance industry, where people are saving along with there is domestic saving, FDI has amplified to 74\% which has brough in capital income. Farmers, poor and vulnerable people have been benefitted with majority of the health insurance policy in India. we also see a rise in digital insurance. In FY21 the non-insurance recorded 5.19\% growth in Growth Direct premiums, where as the market share for general and health insurance has escalated from $47.19 \%$ to $48.3 \%$ for FY20. In this pandemic the main focus in on health insurance, the government is bringing in new schemes for health sector and incrementing its insurance.
\end{abstract}

Keywords: Financial system; Insurance industry; Health; Life and non-life; Private sector; Economy growth

\section{Introduction}

Financial security is very important in today's growing world, everyone wants to be financial independent and saving are important when we start earning, insurance ensures you are financial secured and in future can face any type of problems.Today, we have health insurance, car insurance, travel insurance, home insurance and made other. This insurance is very important to make our life secured and our future generation. We have general insurance like mentioned above, apart from other we have life time insurance. Today, we growing demand, insurance help us to protect our economy. Earlier there used to be only banks which offered insurances, today we many individual companies which offer us insurance, whatever we purchase today, in particular a motor bike or a car

insurance. There are many reason why we require insurance these days and it is becoming necessary financially security -there is no guarantee that what we earn and save with help us in our future, we can anytime face financial imbalance, so we need to insurance our assets, we can purchase or renew insurance online also. Transfer of risks -the contract of insurance works on the transfer of financial risk from the insured to the insurer. You receive compensation from the insurer during the occurrence of an unpredictable event. Insurance reduces the financial burden. It is important to protect your family and yourself to face any unforeseen emergency. Some types of insurance are necessary as it is part of the law. As per the Motor Vehicle Act of 1988, it is necessary to have a third-party motor insurance for motor vehicles. It also makes retirement secured insurance helps you to save some amount of your income for a long term and make you financial stable even after retirement. Insurance also promotes savings. Insurance sector in India is rapidly growing, it has a played a significantly role in promoting the well-being of its economy, the insurance sector contributes to the

* Corresponding author: Dr Sumanta Bhattacharya

MAKAUT, Public-Foreign-Defence Policy, MPI (oxford University) ORCID ID: 0000-0003-2563-2787..

Copyright $(2021$ Author(s) retain the copyright of this article. This article is published under the terms of the Creative Commons Attribution Liscense 4.0. 
capital market by using the funds which help in the infrastructure development of the country. The Insurance sector in India falls under two categories -Life insurance and non-life insurance both of which is governed by the Insurance Regulatory and Development Authority of India (IRDAI). The IRDAI is in charge of monitoring the whole insurance sector and acts as a guardian of all insurance consumers rights. Life insurance in India cover all aspects of the individual life where as non -life insurance is related to day to day activities like health, travel, two wheelers, four wheeler. It also provide insurance for industrial equipment, apart from that we have crop insurance for the farmers, mobile insurance, we have insurance on all kinds of electronic products, the non life insurance is also referred to general insurance, they don't offer total risk to the clients where as Life insurance does.

\subsection{Research Methodology}

For the purpose of this exploration, I have used a amalgamation of two of the archetypical social sciences research tools application -as they are authentic and brilliant method to assemble statistics from multiple appellant in an methodical and convenient way. Question were asked to the common youth, public policy Analyst, urban people.farmers, interviews -consisting of several interrogation which were dispersed among representative of each contender group.

\section{Objective of the Research Paper}

The main areas of exploration in this paper incorporates

- A study on the Insurance sector in India and its benefits.

- How the insurance industry has provided financial security to the people and its type.

- How the insurance sector has contributed to the economic growth

\section{Literature Review}

India has 57 insurance companies, 24 provide life insurance and 33 provide non -life insurance. and 7 belong to the Public sector. Insurance system in India can be trace back to the writing of Yagnavalkya (Dharmasastra), Manu(Manumrithi) and Kautilya(Arthasastra). The writing talked about grouping of resources which could be later used in times of emergency, in times of natural calamities and all. In Modern India, the first insurance was in the form of marine trade loans. 1818 saw the beginning of insurance industrial in India with the formation of oriental Life Insurance company in Calcutta. The company couldn't work after 1834, due to it failure. The Madras Equitable started with life insurance business in Madras Presidency in the year 1829. 1870, the British brough in British Insurance Act which started in Bombay.In 1914, the government finally started taking returns of Insurance company in India.In 1912, the first Indian Life insurance Act was formed to regulate the business. In 1928 the Indian Insurance companies Act was enacted which allow the government to collect statistical data of both life and non life insurance business in India. Finally it was in 1938, that in the view of protecting the interest of pubic insurance, the legislation was accepted and amended.After the Independence of India we have the Insurance Amendment Act of 1950, which ended principal agencies, with the Industrial revolution growing, the system of insurance started in Modern world. Over the years made Insurance policies and act have been passed. Life Insurance Corporation (LIC) is the chef public sector company, for life insurance, with liberalization and privatization taking grounds from 2000s we have saw the emerging of private Insurance sector, before that LIC was the main and most trusted company. With private sector, it has allowed Foreign Direct Investment(FDI) in the insurance sector, where as the limit was set to $26 \%$ in the 2000 s and now it has escalated to $49 \%$ in 2014. In 2012 the Indian Insurance saw a growth of 72 billion US dollar with more and more private companies joining in, particular in the Mediclaim. In western countries like UK and USA they don't require medicinal insurance as they are run by state government. In order to secure the insurance, in September 2013 the IRDA introduced insurance repository service, it is first introduced in India, where the policy makers are asked to purchase and keep the insurance scheme in an electronic form holding it in a single account referred to as electronic insurance account and IRDA has provided license to four agencies to work as Insurance Repository which are CDSL insurance Repository Limited, Kavy Insurance Repository Limited, NDSL Database Management Limited and CAMS Repository Services Limited. Today every person has an insurance or try to get insurance done to secure their future.

\section{Findings}

Insurance is a very old industry, it is deep rooted in our culture, if we go back to the tribes, where some people in the tribe would be hunter some would be blacksmiths, some of them would be goldsmiths and some would be farmers, all would be different roles, there would always be a head of the tribe whose duty was to ensure that the tribe is safe, secured, protected, satisfied and happy. Just with time tribes, moved to cities they formed kingdom people and soldiers use to die, the community and the king use to take the responsibility of the family financial, with time the society become 
so big that the government couldn't control all these things which led to privatize these enterprises, and one of the enterprise was insurance, if any member of the community passed away or fell sick, the community would work together to make sure they are protected and that is the job of the insurance. The small amount of money that is given to the community and the money collected is that pool of money. The pool is then used to pay out anyone who fall sick, pass away, retire, kids go to colleges, that pool is used to pay those money out, the insurance company's job is to protect that pool because there are a lot of people who would try to defraud so they would find a way to make money from it, understand that the pool is for the whole community. Insurance in short is the manager of the pool of money which gets used to pay out to people who needs it, they are people to try to defraud it and that's when investigation comes into place, o insurance companies would investigate claim that they feel are not general that is what is necessary is to understand insurance, understanding the documentation, understanding what is covered and try to sit down with a proper financial advisors.

Insurance is a business which is based only on one thing, be on premiums on time to make sure to cover all eventualities and primary once are, when you pass away the family needs income protection, in case you fall ill the family needs income protection, when you retire you want to have a steady income and when your children go to college you might as well require some money on the side. The various types of insurance available in India are Term insurance, term insurance with return of premium, unit linked insurance, endowment plans, whole life insurance, group life insurance, child insurance plans, retirement plans. The different companies which provide non life insurance in India are Aditya Birla General Insurance, Bajaj Allianz General, Bharti AXA General, Cholamandalam MS General, Digit General Insurance, Edelweiss General Insurance, Future Generali India General,IFFVO Tokio General Insurance, Kotak Mahindra General Insurance, Liberty General Insurance, Max Bupa Health insurance, National General Insurance, Navi General Insurance, SBI General Insurance and many other. The government have many health insurance scheme for its citizen.

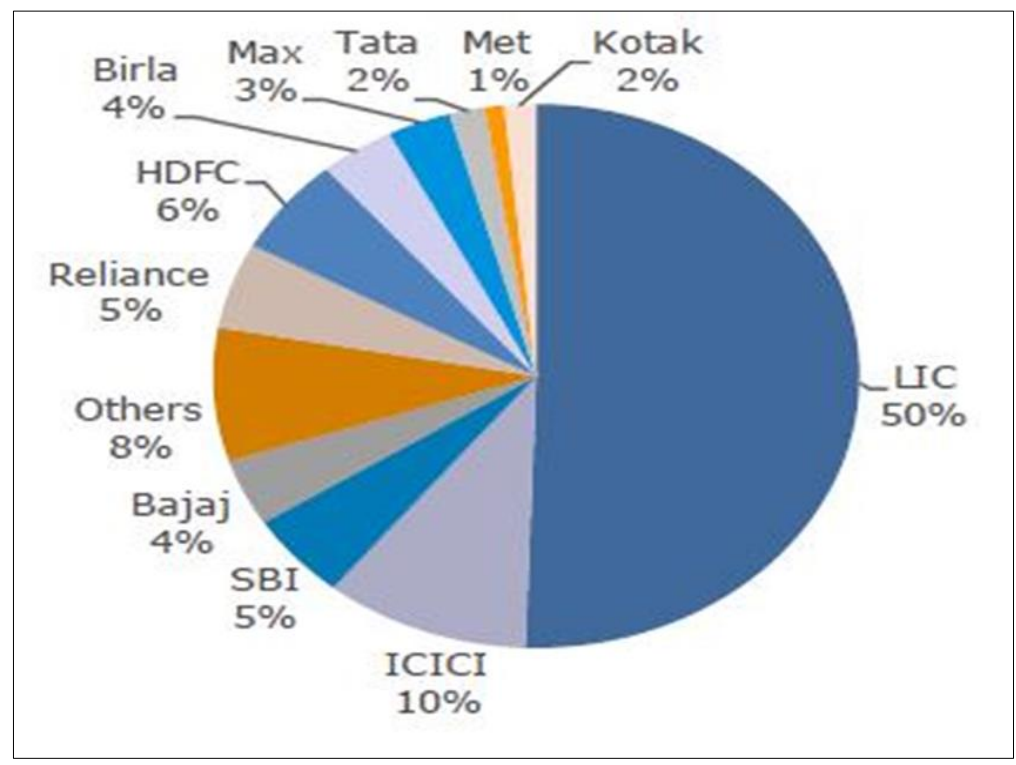

Figure 1 Health insurance scheme

The last two decades have seen, rapid growth with private sector participation and upgradation in distribution capability and improvement in operational efficiencies. Privat life insurers are expected to grow by $17 \%$ in the years $2021-2023$ and new term retail to increase in the coming 5 years, The private genera insurance to grow by $16 \%$ in FY22 and in FY23 by 14\%. Health insurance grow by 25\% in FY22 to increase health care provisions. The New Business Premium for Life has to increase CAGR of 14\% from FY14-0, and from 2020 to 2030 it will grow at 12.5\% CAGR. There is 81.3 billion dollar total written Premium, 92.1billion dollar Gros Direct Premium (Non-Life Insurance), $45.25 \%$ share of new Business Premium in total Premium and 34.1\% share of motor premium in total non life premium, health insurance is 29.5\%.In FY21 the non insurance recorded 5.19\% growth.

Growth Direct premiums, where as the market share for general and heath insurance has escalated from $47.19 \%$ to $48.3 \%$ for FY20.The health insurance aw a rise of 13.3\% growth in GDPI, FY21. The government schemes have aided in adopted and entering all sectors. The crop insurance has brough in 55 million application per years, even during the pandemic 70 lac farmers have been benefitted with INR 87.4 billion benefitted. Under the Ayusharam Bharat scheme which is fully by the government, it is also the largest health care scheme and provides a health cover of $\$ 6900$ per 
family in a year covering 107 million families (Vulnerable families).There is a rise in digital insurance which is gaining momentum, at present there is 30 to $40 \%$ digital insurance.

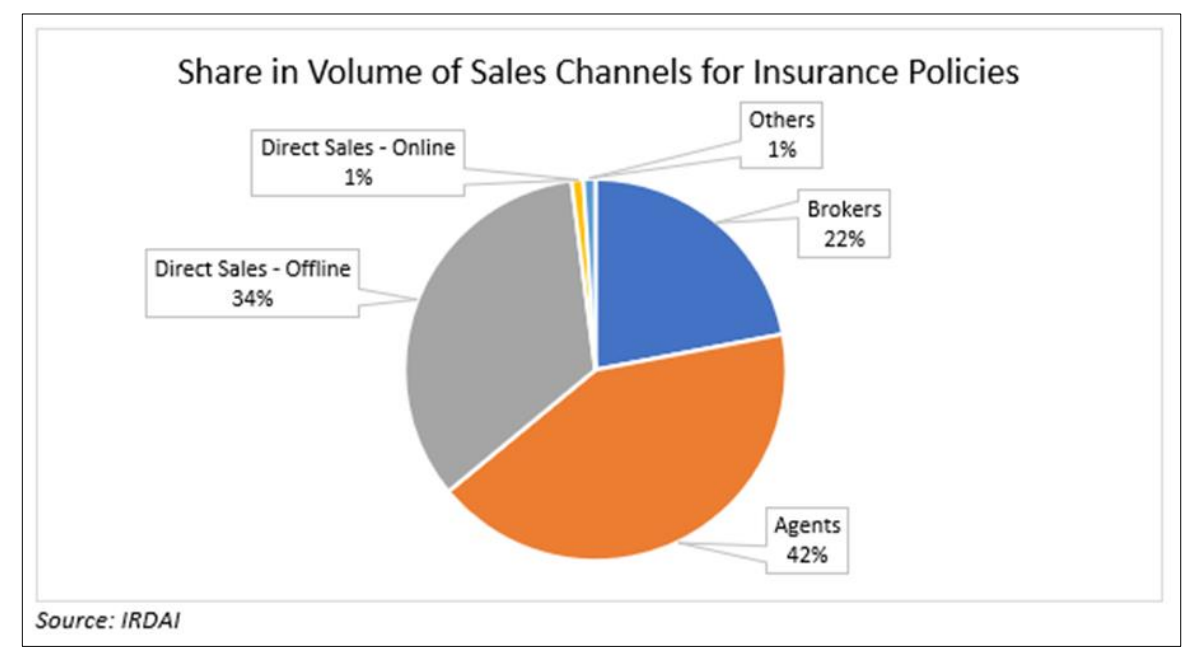

Figure 2 Indicates the share in volume of sales channels for Insurance Policies

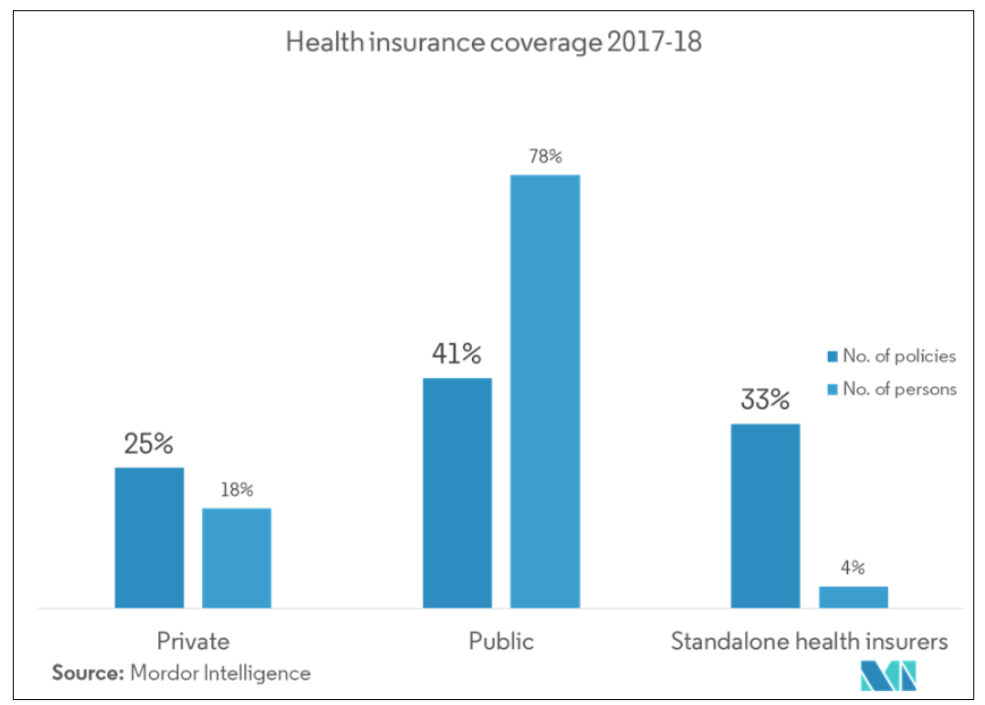

Figure 3 Health Insurance rate for the year 2017-18

The increase in the FDI from 49\% to 74\% have brought has enabled avenue for capital aid.the grown of the insurance industry is being supported by various government initiatives vibrant distribution channels, environment, partnership, innovation products. India is the second largest Insurance Tech Market in the APAC region. During the pandemic situation the focus being much on health insurance.

\section{Proposal}

Looking at the currency situation, insurance is a way for better lifestyle and standard, where even the Middle class family can feel secured and invest in different insurance companies and for different purposes, today because of wheeler and home insurance people are able to spent and purchase more cars and expensive homes. We need to introduce new insurance policy and easy insurances schemes for the poor and low middle class people so that they can move above of their current scenario, we need to bring insurances scheme to the rural region.in village people should be taught about what is insurance and what benefits it can provide to the people and moreover we need to increase our insurance penetration which is very low in India. Looking at the COVID-19 pandemic situation we require better insurance facilitates and schemes. The Banks both public and private should introduce new insurance schemes for the poor and middle class families which will promote them to invest their money and in return be secured. We should make insurance available both digitally and offline for the rural people, easy gold loan insurance for the people. Providing 
easy and less documents required health insurance policies for the poor people, during the time of pandemic everyone is in need of a new health insurance scheme, education loan / insurance for children so that every child both from rural and urban sector can attain education in a healthier way, we need to bring such insurance schemes which gives utmost importance to the conditions of the poor and provide them ample benefits and security.

\section{Conclusion}

The insurance sector over the years have provided us financial sector, at times of unforeseen emergency. The government has introduced many schemes for health insurance and crop insurance which has improved the health sector and doubled the crop productivity. The insurance sector both private and public along with different insurance policies have made the life of people safe and secured, insurance policies have helped many people during this pandemic situation, it has helped in the overall development of the economy, doubled the economy with innovative ideas. Health insurance has saved many people from entering into a state of poverty in this pandemic situation.

\section{Compliance with ethical standards}

\section{Acknowledgments}

Timir Baran Chatterjee: B.com(H). M.com. FCS.ACMA. MBA Manager Partner at Tax Connect Advisory Services LLP Chairman. IDT Chairman. Bengal chamber of commerce and Industry.

Heera Lal: IAS, Additional Mission Director at National Health Mission. Uttar Pradesh. Advisor-Model Gaon Honorary.

\section{Disclosure of conflict of interest}

No conflict of interest.

\section{References}

[1] Dr Sunita Mall. Contribution of insurance on economic growth in India' An econometric Approach, Global Trade Analysis Project.Journal of Applied Business and Economics. 2018 20(2)

[2] Steven Weisbart. How insurance drives economic growth, Insurance Informative Institute. 2018.

[3] Patrick M Liedtke. What's Insurance to a Modern Economy?, JSTOR. 2007.

[4] Rana Rohit Singh, Abhishek Singh. A study of Health insurance in India, International Journal of Management, IT \& Engineering. 2020; 1(4).

[5] Rajeev Ahuja. Health Insurance for the poor in India, Indian Council for Research on International Economic Relations. Econ Papers.2005

[6] Prinja S, Bahuguna P, Gupta I, Choudhury S, Trivedi M. Role of insurance in deterring utilization of Health care and financial risk protection in India, PLOS One. 2019

[7] A Muthusamy, Janirani P. Preference of Vehicle Insurance Based on Premium, Retention and Claim, International Journal of Advanced Science and Technology. 2020; 29(3).

[8] Sunila George, Raghbendra Ja, Hari Krishnan Nagarjan. The Evolution and Structure of the Two Wheeler Industry in India, SSRN Electronic Journal. 2000; 29.

\section{Author's Short Biography}

Dr Sumanta Bhattacharya is a Research Scholar at MAKAUT and a Public-Defence-Foreign
Policy Analyst. He has 180 research papers, 27 Patents and 27 Book chapters, holds the
record for maximum number of degree courses, have won International and national
awards for his excellences in Education and Policy Making

